\title{
Effect of Millennial Orientation on Intention to Leave with Engagement and Job Satisfaction
}

\author{
${ }^{1}$ Effendi MEIZAR \\ 1. First Author University of Brawiiaya, Email: meizareffendi@ @student.ub.ac.id
}

Received: May 21, 2020. Revised: July 13, 2020. Accepted: July 13, 2020

\begin{abstract}
Purpose: We explore to find out and analyze the direct influence of Millennial Orientation on Goals Mediated by work engagement and satisfaction. And, interaction cannot be a direct relationship between research variables. Method: The implementation uses the survey method. This research was conducted at PT. East Kalimantan fertilizer operated in Bontang, East Kalimantan. The population in this study were all employees of PT. East Kalimantan fertilizers operated in Bontang, as many as $\mathrm{N}=500$ people. The sampling technique used is proportional stratified random sampling. Findings: Millennial orientation influences engagement, job satisfaction and intention to leave, direct engagement has a significant effect on job satisfaction and intention to leave, and job satisfaction is directly related to intention to leave. Originality: Alignment between millennial goals in encouraging job satisfaction and employee engagement, so that it can have an impact on the intention to leave employees, especially at PT. Pupuk. Kaltim. Also, direct millennials as decreasing intention to leave.
\end{abstract}

Keywords: Millennial Orientation, Engagement, Job Satisfaction, Intention to Leave

JEL Classifications: J23, J28, J29.

\section{Introduction}

Human Resources (HR) is one of the company's most valuable assets. Excellent and professional and competent human resources in the field of technology are also very much needed and become the main element to support the company's operations. HR management is an important activity in a company. Companies need to manage human resources in order to achieve their goals effectively and always maintain and create comfortable conditions at work. HR management in the current era needs proper planning and handling, because there is a very high dynamics, especially in the millennial generation (generation Y, born after 1980). This can encourage increased employee performance, which in turn affects the performance and success of the company. Millennial era changes in the orientation of the employees, not only in the millennial generation but also in generation $\mathrm{X}$ employees (range born in 1961 - 1980). Therefore, the issue of HR or employees is a serious matter that needs attention by the company.

In addition, companies need employees who have an Engagement to work and organizations that make it comfortable to work. According to Bakker \& Leiter (2010) that employees who have high Engagement will show enthusiasm in 
working and using energy in carrying out their work optimally. Another important and related component to employees is job satisfaction (job satisfaction). Job satisfaction is an aspect in managing human resources and organizational behavior. Job satisfaction is satisfaction with every treatment they receive at work (Panggabean, 2004). Employee satisfaction is important for the company because it is directly proportional to the performance produced.

On the other hand, every company needs to pay attention to Intention to Leave which is an important aspect covered in human resource management. Almost every company certainly cannot avoid the Intention to leave employees. Intention to leave is the desire of an employee to move, stop or leave the workplace that is done voluntarily and based on one's own desires and organizational decisions. Intention to Leave is unavoidable and can harm the company. Another problem that will arise is the decline in productivity caused by the loss of employees until there is a replacement for new employees.

PT. Pupuk Kaltim is a state-owned company which is a subsidiary of PT. Pupuk Indonesia (Persero). Kaltim Fertilizer Company makes a goal to carry out integrated business activities ranging from industry, trade, distribution and services in the field of fertilizer, petrochemical and other chemicals. Also, use company resources to produce high-quality goods and services, are highly competitive and ready to support National Food Security. It is one of the missions of PT. Pupuk Kaltim optimizes resources in the surrounding environment or global markets supported by internationalminded human resources using cutting edge technology. To overcome the development of the business environment.

The occurrence of Intention to leave a special assignment in the HR field at PT. Pupuk Kaltim. However, PT Pupuk Kaltim is able to control safety to support the company. One form of innovation is employee turnover. PT employees. Pupuk Kaltim who resigned has increased and has been receiving a significant increase in permanent employees. In 2017 PT. Pupuk Kaltim, the turnover rate of the company which has the largest contribution from the number of employees to 150 people, was followed by mutations based on PIHC directives of 7 people, 5 people died, resigned as many as 3 people, and early income was 1 person. On the other hand, from the recruitment program with PIHC, Pupuk Kaltim accepted 14 new employees. This increased from the previous year which was followed by a normal turnover trend at PT. Pupuk Kaltim. Related to the employee turnover rate at PT. East Kalimantan low fertilizer. However, the degree of intention to leave at PT. Pupuk Kaltim needs to be studied, especially with regard to millennial generation employees.

Some research on the proposed variables on employee engagement was carried out by Samala and Singh (2018). Where discussing the significant and positive influence on employee engagement. In addition, job satisfaction is one of the important variables that can be used to reduce the intention to leave employees. Therefore, increasing job satisfaction is important. Several studies of variables aimed at employee satisfaction are millennially determined variables, which are significant and positive for employee job satisfaction (Purba and Ananta, 2018; Cruz et al., 2018).

The relationship between employee Engagement and intention to leave has occurred by Kim and Hyun (2017), Merissa (2018), and Rachmatan \& Kubatini (2018), where company Engagement has a significant and negative effect on the intention to leave. On the other hand, some research results show that employee job satisfaction is also significant and negative about the intention to leave (Balabanova et al., 2016; Ahmad et al., 2018). Based on this, it is necessary to align between millennial-driven in the encouragement of job satisfaction and employee engagement, so that it can have an impact on the intention to leave employees, especially at PT. Pupuk Kaltim. Therefore, this study examines the development of the concept or model of Intention to leave, by positioning the millennial orientation variable as a driver, as well as the Engagement and job satisfaction variables as a link to the Intention to Leave variable.

The relationship between several variables with the intention to leave already exists. Eberhardt et al. (1995) discuss with research subjects of nurses in hospitals, the result is the relationship between job satisfaction and nurses' intention to quit is significant. Balabanova et al. (2016) conducted research in Russia, with LMM analysis. The outcome variable satisfaction with wages as the strongest negative predictor of employee intention to leave compared with core satisfaction related to work and interpersonal relationships. In Yuen's study (2016) about employees from the millennial generation in Hong Kong Associated with the previous generation of employees have lower job satisfaction than the previous generation. Ahmad et al. (2018) agreed with the results requested by the approved police and were satisfied with the professionals agreeing to leave their organization. In addition, alternative job opportunities appeal to the relationship of professional commitment and job satisfaction with leave intentions. Research involving aspects 
of conversation, Engagement, and satisfaction with the effects of intention on leaving intentions is still rare. On the other hand, searching through literature, research involving all variables that have not been found simultaneously. This gives an opportunity to do research or in other words contain deficiencies that can be allocated. The research was conducted on the employees of PT. Pupuk Kaltim. As a novelty of this research, the renewal of ideas and differences with previous studies is to study the concept or model of Intention to leave that is aligned in the Y generation era, by including variables used as independent variables and work variables as well as job satisfaction as mediation.

\section{Literature Review}

\subsection{Millennial Orientation}

Development of the concept of Millennial Orientation refers to two words, namely Orientation and Millennial. According to KBBI Orientation is the view that underlies thoughts, concerns or tendencies. Millennial Orientation is a derivative variable of the parent variable, which is the value orientation variable (Fernandes et al., 2015). The value orientation is complex but it is patterned on principles that prioritize order and directly on the actions and thoughts of humans that are related to solutions in solving problems. There are three assumptions, namely: (1) people in all cultures must find solutions to solve problems; (2) unlimited solutions available; (3) one solution tends to be chosen by members of a particular culture. All potential solutions appear in every culture (Fernandes et al., 2014).

Generation Y, known as millennial generation, is the most diverse and youngest generation in the world of work today, born between 1982 and 2002. They grew up in a culturally diverse and playful school environment, were tech savvy, enthusiastic, selfish, confident, good networking and meeting oriented (Lapaseotes, 2015). As a group, millennials have characteristics that distinguish them from previous generations. Millennial generation is pragmatic, achievement oriented, and hardworking. They are confident and optimistic about their future. They are very collaborative and team oriented, in contrast to the stereotypical "loners" of Generation X. They value the ideas of others, both adults and their peers, and they hope their ideas support and support each other. The most diverse generation, they are open-minded and socially aware (Wheeler \& Harris, 2008). According to Howe and Strauss (2000), Millennial Orientation has characteristics that include Bureaucracy Orientation, Team Orientation, Leadership Orientation, Time Orientation, Attitude Orientation, Career Orientation, Behavior Orientation, Behavioral Orientation, Job Orientation, communication Orientation

\subsection{Engagement}

Kahn (1990) defines work engagement as the empowerment of organizational members to their work roles. In engagement, people use and express themselves physically, cognitively, and emotionally while demonstrating their performance. According to Kahn (1990) there are two concepts that emerge from a person's behavior towards work involvement, namely personal engagement and disengagement. Meanwhile according to Schaufelli et al. (2004) employee engagement is a positive condition, attitude or behavior of an employee towards work and organization characterized by:

1. Vigor

2. Dedication

3. Absorption

An employee who has a high level of engagement in an organization has an understanding and concern for the organization's operational environment, is enthusiastic at work, is able to work together with other employees, talks positively about the organization and goes beyond organizational expectations.

\subsection{Job Satisfaction}

According to Truxillo et al. (2016) Job satisfaction is a pleasant or positive emotion that results from one's work or work experience. Meanwhile, organizational commitment is a part which is identified and applied by companies in the organization. In addition, according to Locke (1969) job satisfaction is a pleasant emotional condition that results 
from one's work as the success or ease of assessing the value of one's work. According to Hays (2014), job satisfaction is an emotional response or general feeling towards various aspects of work. Job satisfaction is closely related to the performance and quality of work performed by an employee, and translates into organizational success. Only satisfied employees can participate and build organizational success. Liao et al. (2017) defines job satisfaction as a pleasant or positive emotional condition resulting from the assessment of one's work given one's work experience. This was confirmed by Seal and Knight in Liao et al. (2017) who conceptualizes satisfaction from a psychological point of view: job satisfaction means an emotional response or an overall evaluation of employees for the job itself. From the opinions of the experts above, it can be concluded that job satisfaction is the emotional response of employees to their jobs. The assessment of job satisfaction consists of three elements involved, namely 1) perception of several job compositions; 2) implicit or explicit value standards; and 3) conscious and unconscious of the relationship between one's perception and one's values. Someone's job satisfaction can be predicted and discussed in the short term by considering his specific goals. However, to achieve this in the long run, one must consider the broader values. For these broader values, determine future goals that people will look for after reaching their present goals.

\subsection{Intention to Leave}

According to Halawi (2014), Intention to Leave or turnover is the desire or intention of employees to stop working. This desire without compulsion to follow his own conscience. This is a way for employees to express their dissatisfaction with work or other matters by leaving the company. The turnover model developed by March and Simon (1958), predicts things that affect the person's desire to leave the organization, namely an evaluation of one's current position regarding dissatisfaction can trigger one's desire to leave and find another job. The intention to move variable is significantly related to and can be used to predict the actual turnover rate as shown in previous studies that use the intention to move variable and turnover rate simultaneously, thus, the organization can evaluate the results of the study with respect to the actual turnover rate faced. Turnover describes the individual's thoughts of going out, finding work elsewhere, and the desire to leave the organization. From the psychological side that organizational climate will emerge as a significant predictor for employee desires to leave the company (turnover). Agguirre et al. (2015) conducted a study in measuring intention to leave. This study shows that there are six indicators, including Spaces and Job Content, Perceived Supervisory Support, Perceived Peer Support, Available Opportunities outside the Organization, Work-family Conflicts, and Organizational Extrinsic Motivators.

\section{Research Method}

The approach used in this study is a quantitative approach, in which the implementation uses a survey method. This research was conducted at PT. East Kalimantan fertilizer which operates in Bontang, East Kalimantan. The population in this study were all employees of PT. East Kalimantan fertilizers operating in Bontang, as many as $\mathrm{N}=500$ people. The sampling technique used, namely proportional stratified random sampling, the sampling process is carried out by random / random at each level (age level). So that a total sample of $n=250$ employees was obtained. Measurement of variables in this study using a questionnaire by applying a Likert Scale. The response items used are in the range of scales from 1 to 5 . There are two analyzes carried out namely descriptive analysis and SEM WarpPLS approach. The following conceptual model for the research is presented in Figure 1. 


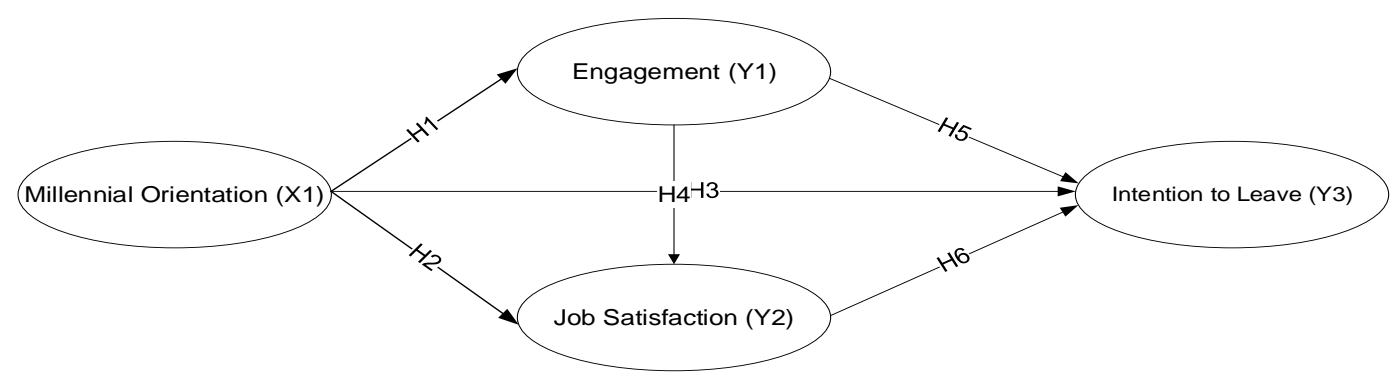

Figure 1: Conceptual Research Model

Following is the research hypothesis:

H1: Millennial orientation has a significant effect on Engagement

H2: Millennial orientation has a significant effect on Job Satisfaction

H3: Millennial orientation has a significant effect on Intention to Leave

H4: Engagement has a significant effect on job satisfaction

H5: Engagement has a significant effect on Intention to Leave

H6: Job satisfaction has a significant effect on Intention to Leave

\section{Results}

Data obtained from the questionnaire were analyzed using WarpPLS. Millennial Orientation Variables, Engagement, Job Satisfaction and Intention to leave using the reflective indicator model. Table 1 is an outer loading table and averages of research variables.

Table 1: Variable Measurement

\begin{tabular}{|c|c|c|c|}
\hline Variable & Indicator & Outer Loading & Variable Average \\
\hline \multirow{9}{*}{ Millennial Orientation (X) } & $\begin{array}{l}\text { Bureaucracy Orientation } \\
(\mathrm{X} 1)\end{array}$ & 0.678 & 3.97 \\
\hline & $\begin{array}{l}\text { Leadership Orientation } \\
\text { (X2) }\end{array}$ & 0.683 & 4.53 \\
\hline & Time Orientation (X3) & 0.608 & 3.96 \\
\hline & $\begin{array}{l}\text { Attitude Orientation } \\
\text { (X4) }\end{array}$ & 0.711 & 3.94 \\
\hline & Career Orientation (X5) & 0.385 & 3.68 \\
\hline & $\begin{array}{l}\text { Behavioral Orientation } \\
\text { (X6) }\end{array}$ & 0.598 & 4.18 \\
\hline & Job Orientation (X7) & 0.651 & 3.49 \\
\hline & $\begin{array}{l}\text { Communication } \\
\text { Orientation }(\mathrm{X} 8)\end{array}$ & 0.744 & 3.68 \\
\hline & Team Orientation (X9) & 0.658 & 4.42 \\
\hline \multirow{3}{*}{ Engagement (Y1) } & Vigor (Y1.1) & 0.843 & 4.29 \\
\hline & Dedication (Y1.2) & 0.889 & 4.26 \\
\hline & Absorption (Y1.3) & 0.870 & 4.25 \\
\hline \multirow{2}{*}{ Job Satisfaction (Y2) } & Job itself (Y2.2) & 0.720 & 4.05 \\
\hline & Supervision (Y2.2) & 0.754 & 4.25 \\
\hline
\end{tabular}




\begin{tabular}{|l|l|l|l|}
\hline & Rewards (Y2.3) & 0.763 & 4.00 \\
\hline & $\begin{array}{l}\text { Promotion Opportunities } \\
\text { (Y2.4) }\end{array}$ & 0.775 & 4.21 \\
\hline $\begin{array}{l}\text { Workplace Atmosphere } \\
\text { (Y2.5) }\end{array}$ & 0.807 & 4.24 \\
\hline \multirow{5}{*}{ Intention to Leave (Y3) } & $\begin{array}{l}\text { Spaces and Job Content } \\
\text { (Y3.1) }\end{array}$ & 0.646 & 2.41 \\
\hline $\begin{array}{l}\text { Perceived Supervisory } \\
\text { Support (Y3.2) }\end{array}$ & 0.702 & 2.08 \\
\hline $\begin{array}{l}\text { Perceived Peer Support } \\
\text { (Y3.3) }\end{array}$ & $\begin{array}{l}\text { Available Opportunities } \\
\text { Outside the Organization } \\
\text { (Y3.4) }\end{array}$ & 0.682 & 2.09 \\
\hline $\begin{array}{l}\text { Work-family Conflicts } \\
\text { (Y3.5) }\end{array}$ & 0.777 & 2.48 \\
\hline $\begin{array}{l}\text { Organizational Extrinsic } \\
\text { Motivators (Y3.6) }\end{array}$ & 0.728 & 2.31 \\
\hline
\end{tabular}

Based on Table 1, it can be seen that the millennial orientation variable measured by nine indicators shows that the most dominant indicator influencing the Millennial Orientation (X1) is Communication Orientation (X1.8) with an outer loading value of 0.744 with an average value of 3.68. This indicates that the communication orientation of PT Pupuk Kaltim's employees is included in the good category. Furthermore, there are three significant indicators measuring the Engagement variable (Y1), namely Vigor, Dedication, absorption. The dedication indicator has an outer loading value of 0.889 with an average value of 4.26 which means that the dedication indicator measures the strongest Engagement variable and in real conditions at PT Pupuk Kaltim This indicator is already very good. In the variable Job satisfaction (Y2) which is measured significantly by five indicators including the Job itself, Supervision, Rewards, Opportunity for Promotion, Workplace Atmosphere. However, the indicator that measures the strongest variable Job satisfaction is the Workplace Atmosphere indicator (Y2.5) with an outer loading value of 0.807 and an average value of 4.24. Finally, the variable intention to leave (Y3) the strongest measuring indicator is Work - family Conflicts (Y3.5) with an outer loading value of 0.777 and an average of 2.31. This shows that Intention to leave is very low in PT Pupuk Kaltim employees.

\subsection{Hypothesis Testing: Direct Effects and Indirect Effects}

\subsubsection{Direct Effect}

There are six hypotheses of direct influence in this study. The results of tests conducted using WarpPLS software are presented in Table 2.

Table 2: Hypothesis testing for direct influence

\begin{tabular}{|l|l|l|}
\hline Relationship Between Variables & Path coefficient & P-value \\
\hline $\begin{array}{l}\text { Millennial Orientation to } \\
\text { Engagement }\end{array}$ & 0.320 & $<0.001$ \\
\hline $\begin{array}{l}\text { Millennial Orientation towards Job } \\
\text { Satisfaction }\end{array}$ & 0.186 & 0.001 \\
\hline $\begin{array}{l}\text { Millennial Orientation towards } \\
\text { Intention to Leave }\end{array}$ & -0.279 & $<0.001$ \\
\hline Engagement to Job Satisfaction & 0.339 & $<0.001$ \\
\hline Engagement to Intention to Leave & -0.296 & $<0.001$ \\
\hline $\begin{array}{l}\text { Keja's Satisfaction with Intention to } \\
\text { Leave }\end{array}$ & -0.285 & $<0.001$ \\
\hline
\end{tabular}

Based on the test in Table 2, the results show that the influence has a p-value less than 0.05 , which means that the influence between the research variables is significant. 


\subsubsection{Indirect Influence Testing}

Table 3: Hypothesis testing for indirect effects

\begin{tabular}{|l|l|l|l|l|}
\hline Variables & $\rightarrow$ & Dependent & \multirow{2}{*}{ Coefficient } & \multirow{2}{*}{ P-value } \\
\hline Independent & $\rightarrow$ & Job Satisfaction (Y2) & 0.109 & 0.007 \\
\hline Millennial Orientation (X) & $\rightarrow$ & Intention To Leave (Y3) & -0.148 & 0.009 \\
\hline Millennial Orientation (X) & $\rightarrow$ & Intention To Leave (Y3) & -0.097 & 0.014 \\
\hline Job Satisfaction (Y1) & & & \\
\hline
\end{tabular}

Based on testing in Table 3, the results show that the influence has a p-value less than 0.05 , which means that the influence between the research variables is significant.

\section{Discussion}

\subsection{Effect of Millennial Orientation on Engagement}

Hypothesis 1 examines between Millennial Orientation (Bureaucracy Orientation (X1), Leadership Orientation (X2), Time Orientation (X3), Attitude Orientation (X4), Career Orientation (X5), Behaviour Orientation (X6), Job Orientation (X7), Time Orientation (X3), Attitude Orientation (X4), Career Orientation (X5), Behavioural Orientation (X6), Job Orientation (X7), Communication Orientation (X8) and Team Orientation (X9) towards Engagement (Vigour (Y1.1), Dedication (Y1.2) and Absorption (Y1.3)) obtained path coefficient of 0.320 with p-value <0.001, so that Hypothesis 1 This means that millennial orientation has a significant effect on Engagement. Research develops Ozcelik's research (2015) which conducts research to explore millennial characteristics and millennial work orientation characteristics. In addition, this study is in line with the study of Park \& Gursoy (2012) which states that the level of work involvement depends on the presence of a generation of employee's significant influence and positive direction. This study develops Park \& Gursoy (2012) research that the involvement is not only a depends on the level of generation of employees but on the orientation of that generation especially the Millennial Orientation which is more dominant in this era of globalization. It is shown that there is an orientation that encourages work engagement, namely an orientation in communication to encourage increased employee dedication. Besides this research the way with the Cattermole study (2018) which produces a positive direction between teamwork will influence millennial generation in the presence of workplace involvement so that it is able to engage with the company. PT Pupuk Kaltim must improve the communication orientation of employees to encourage work engagement. Work engagement is an important aspect in a company to support good performance and is useful for achieving the vision and mission of PT Pupuk Kaltim.

\subsection{Effect of Millennial Orientation on Job Satisfaction}

Hypothesis 2 which examines between Millennial Orientation (Bureaucracy Orientation (X1), Leadership Orientation (X2), Time Orientation (X3), Attitude Orientation (X4), Career Orientation (X5), Behavioural Orientation (X6), Job Orientation (X7), Time Orientation (X3), Attitude Orientation (X4), Career Orientation (X5), Behaviour Orientation (X6), Job Orientation (X7), Communication Orientation (X8), and Team Orientation (X9) towards Job Satisfaction (Work itself (Y2.1), Supervision (Y2.2), Rewards (Y2.3), promotion opportunities (Y2.4) and Workplace atmosphere (Y2.5)) obtained path coefficient of 0.186 with a p-value of 0.001 , so that Hypothesis 2. This means that millennial orientation has a significant effect on job satisfaction. job satisfaction Millennial Orientation in this study shows that Communication Orientation (X1.8) is the most dominant form of Millennial Orientation. This study is in line with research conducted by Garcia et al. (2018) which conducted research aimed at achieving know the effect of employee involvement in the workplace and its effect on job satisfaction for millennial workers. This study is different from the study of Garcia et al. (2018) because this research found a new concept regarding Millennial Orientation instead of generation. However, this study is not in line with the results of the research of Hays (2014) and Smith Nichols (2015), 
namely millennial generation has the need to feel connected to someone. Millennial employees need specific, timely and relevant feedback using technology such as social media tools. Hays's (2014) study revealed that Millennials believed that their relationship with their immediate supervisor was important, and they were not satisfied with this relationship because Millennial needed specific, timely, and relevant feedback.

\subsection{Effect of Millennial Orientation on Intention to Leave}

Hypothesis 3 which examines between Millennial Orientation (Bureaucracy Orientation (X1), Leadership Orientation (X2), Time Orientation (X3), Attitude Orientation (X4), Career Orientation (X5), Behaviour Orientation (X6), Job Orientation (X7), Time Orientation (X3), Attitude Orientation (X4), Career Orientation (X5), Behavioural Orientation (X6), Job Orientation (X7), Communication Orientation (X8), and Team Orientation (X9) towards Intention to Leave (Spaces and Job Content (Y3.1), Perceived Supervisory Support (Y3.2), Perceived Peer Support (Y3.3), Available Opportunities Outside the Organization (Y3.4), Work-family Conflicts (Y3.5) and Organizational Extrinsic Motivators (Y3.6)) obtained path coefficient of -0.279 with p-value $<0.001$. The direction of influence of millennial orientation on Intention to Leave is negative, which means increasingly the higher the millennial orientation, the lower the Intention to Leave of PT Pupuk Kaltim employees, supporting the influence of Millennial Orientation on Intention to Leave, there are four supporting studies. The results of this study support the research conducted by Campione (2015), Frian Mulyani (2018), and George \& Wallio (2017) and Ertas (2015) ie millennial generation are more likely to report intention to leave their jobs and most other attributes are not more important for millennial generation decisions to leave work.

\subsection{Effect of Engagement to Job Satisfaction}

Hypothesis 4 which examines Engagement (Vigour (Y1.1), Dedication (Y1.2) and Absorption (Y1.3)) to Job Satisfaction (Work itself (Y2.1), Supervision (Y2.2), Rewards (Y2.2) Y2.3), promotion opportunities (Y2.4) and workplace atmosphere (Y2.5)) obtained path coefficient of 0.339 with p-value $<0.001$. Therefore, Hypothesis 4 is accepted. That is, so, the higher the Engagement the higher the job satisfaction. This indicates that the involvement of PT Pupuk Kaltim employees in the company will increase the job satisfaction of PT Pupuk Kaltim employees. The results of this study are in line with the research of Karatepe and Karadas (2015) which shows that optimism seems to be the best indicator of psychological capital, followed by resilience, self-efficacy and hope. Employees with high psychological capital are involved in their work at a higher level. In addition, the study of Yalabik et al. (2017) conducted research aimed at analysing the relationship between aspects of job satisfaction and job involvement. This research supports research that has been done by Karanika-Murray et al. (2015) and Lu et al. (2016) which produces a positive and significant effect between engagement to job satisfaction.

\subsection{Effect of Engagement to Intention to Leave}

Hypothesis 5 that tests between Engagement (Vigour (Y1.1), Dedication (Y1.2) and Absorption (Y1.3)) on Intention to Leave (Spaces and Job Content (Y3.1), Perceived Supervisory Support (Y3.2) ), Perceived Peer Support (Y3.3), Available Opportunities Outside the Organization (Y3.4), Work-family Conflicts (Y3.5) and Organizational Extrinsic Motivators (Y3.6)) obtained path coefficient of -0.296 with p-value <0.001. So, Hypothesis 5 is accepted. That is, so, the higher the Engagement, the higher the Intention to Leave. The direction of influence of Engagement to Intention to leave has a negative effect. Thus, the higher the Engagement, the lower the Intention to Leave PT Pupuk Kaltim employees. This indicates that the involvement of PT Pupuk Kaltim employees in the company will reduce the desire to move or leave the company. This study is in line with research Memon et al. (2014) who examined the relationship between engagement to Intention to Leave. The results showed that work engagement would mediate the relationship between person-organization compatibility and turnover intention. Values and appropriateness of objectives) will provide greater meaningfulness and psychological Engagement, which will then direct the individual to a higher level of employee involvement. In the long run, individuals with higher levels of employee involvement will tend to leave the organization. In addition, in line with Gupta \& Shaneen's (2017) research which aims to examine the role of psychological capital moderation in work engagement and employee turnover relationships using hierarchical regression tests. Robyn \& Preez (2013) conducted a study between engagement regarding the desire to leave the 
generation academy at tertiary institutions. Robyn \& Preez's (2013) research results show that employee engagement significantly influences intention to quit.

\subsection{Effect of Job Satisfaction on Intention to Leave}

Hypothesis 6 examines between job satisfaction (work itself (Y2.1), supervision (Y2.2), rewards (Y2.3), promotion opportunities (Y2.4) and workplace atmosphere (Y2.5)) on Intention to Leave (Spaces and Job Content (Y3.1), Perceived Supervisory Support (Y3.2), Perceived Peer Support (Y3.3), Available Opportunities Outside the Organization (Y3.4), Work-family Conflicts (Y3.5) ) and Organizational Extrinsic Motivators (Y3.6)) obtained path coefficient of -0.285 with p-value $<0.001$. So, Hypothesis 6 is accepted. That is, there is a significant influence between job satisfaction on Intention to Leave. The direction of the influence of job satisfaction on Intention to leave has a negative effect. Thus, the higher an employee is satisfied with his job, the lower the Intention to Leave PT Pupuk Kaltim. This indicates that job satisfaction within PT Pupuk Kaltim employees at the company will reduce the desire to move or leave the company. The results of this study which show a negative and significant influence are supported by research by Alzayed and Murshid (2017), Robyn and Preez (2013), and Salam (2017). In detail, the study of Alzayed and Murhsid (2017) conducted a study to examine the factors influencing employees' intention to leave their current job. Research conducted at the Ministry of Information in Kuwait. The results showed that the negative relationship between work involvement and intention to leave work. Furthermore, Robym and Preez's (2013) research results that job satisfaction significantly influences intention to quit and has a negative effect. Then Salam's research (2017) explains that in an organization employee turnover is a serious problem for companies to compete in the long run.

\section{Conclusions and Implications}

Based on the analysis results, it can be concluded that Millennial Orientation influences Engagement, Job Satisfaction and Intention to Leave, Direct Engagement has a significant effect on Job Satisfaction and Intention to leave, and Job Satisfaction has a significant direct effect on Intention to leave. Then, for the indirect effect shows significant results. That is, Engagement becomes a mediating variable between millennial orientation towards satisfaction and intention to leave. The Job Satisfaction variable becomes a mediating variable between the relationship of Engagement to Intention to Leave. The research implications for employees within PT. Pupuk Kaltim can use the results of this study as a perspective to get information about HR development programs conducted by the company. Thus, they can actively participate in the program, so that it can help reduce their Intention to Leave and ultimately improve employee performance. Whereas for PT Pupuk Kaltim, it can be used to transform development policies and develop human resources, so that it can suppress Intention to leave, which can then boost company performance. This will be able to drive increased company performance which in turn the company is able to face the challenges of the company in the future so that sustainability can be guaranteed.

\section{References}

Aguirre, L. R. D. (2019). The mediating effects of external factors on intention to leave and organizational factors of hotel industry. Contaduría y Administración, 64(3), 1-18.

Ahmad, R., Islam, T., \& Saleem, S. (2018). How commitment and satisfaction explain leave intention in police force?. Policing: An International Journal of Police Strategies \& Management, 3(4), 394-406.

Alzayed, M., \& Murshid, M.A. (2017). Factors Influencing Employees' Intention to Leave Current Employment in the Ministry of Information in Kuwait. European Journal of Business dan Management, 9(12), 112 - 126.

Bakker, A.B., \& Leiter, M.P. (2010). Work engagement: a handbook of essential theory and research. New York: Psychology Press.

Balabanova, E., Efendiev, A., Ehrnrooth, M., \& Koveshnikov, A. (2016). Job satisfaction, blat and intentions to leave among blue-collar employees in contemporary Russia. Baltic Journal of Management, 11(1), 21-43.

Cattermole, G. (2018). Creating an employee engagement strategy for millennials. Strategic HR Review, 17(6), 290294. 
Cruz, G. G., Gonzales-Miranda, D. R., Gallo, O., \& Roman-Calderón, J. P. (2018). Employee Involvement and Job Satisfaction: A Tale of the Millennial Generation. Universidad Eafit

Eberhardt, B. J., Pooyan, A., \& Moser, S. B. (1995). Moderators of the Relationship Between Job Satisfaction And Nurses' intention To Quit. The International Journal of Organizational Analysis, 3(4), 394-406.

Ertas, N. (2015). Turnover Intentions and Work Motivations of Millennial Employees in Federal Service. Public Personnel Management. Hal. 1-23

Fernandes, A.A.R., Budiantara, I.N., Otok, B.W., and Suhartono (2015). Spline Estimator for Bi-Responses and MultiPredictors Nonparametric Regression Model in Case of Longitudinal Data. Journal of Mathematics and Statistics, 11(2), 61-69.

Fernandes, A.A.R., Nyoman Budiantara, I., Otok, B.W.Suhartono (2014). Reproducing Kernel Hilbert space for penalized regression multi-predictors: Case in longitudinal data. International Journal of Mathematical Analysis, 8(40), 1951-1961.

Frian, A., \& Mulyani, F. (2018). Millenials Employee Turnover Intention in Indonesia. Innovative Issues and Approaches in Social Science, 11 (3), 12 - 126.

George, J., \& Wallio, S. (2017). Organizational justice and millennial turnover in public accounting. Employee Relations, 39 (1), $112-126$.

Halawi, A. H. (2014). Stimuli and effect of the Intention to leave the organization. European Scientific Journal. 10(10), 1, 184-198. https://doi.org/10.19044/esj.2014.v10n10p\%p.

Hays, D. W. (2014). Examining differences between Millennial and all employee levels of job satisfaction and importance and satisfaction with the immediate supervisor relationship. International Journal of Management Studies and Research, 2(8), 1-7.

Howe, N., \& Strauss, W. (2000). Millennials rising: The next great generation. New York: Vintage Books

Kahn, W. A. (1990). Psychological conditions of personal engagement and disengagement at work. Academy of Management Journal, 33(4), 692-724.

Karanika-Murray, M., Duncan, N., Pontes, H. M., \& Griffiths, M. D. (2015). Organizational identification, work engagement, and job satisfaction. Journal of Managerial Psychology, 30(8), 1019-1033.

Karatepe, O. M., \& Karadas, G. (2015). Do psychological capital and work engagement foster frontline employees' satisfaction? A study in the hotel industry. International Journal of Contemporary Hospitality Management, 27(6), 1254-1278.

Kim, W., \& Hyun, Y. S. (2017). The impact of personal resources on turnover intention: The mediating effects of work engagement. European Journal of Training and Development, 41(8), 705-721.

Lapaseotes, C. (2015). The Focus My Millennial Generation Needs.

Liao, S. S., Hu, D. C., Chung, Y. C., \& Chen, L. W. (2017). LMX and employee satisfaction: mediating effect of psychological capital. Leadership \& Organization Development Journal, 38(3), 433-449.

Limba, R.S., Hutahayan, B., Solimun, \& Fernandes, A.A.R. (2019), "Sustaining innovation and change in government sector organizations: Examining the nature and significance of politics of organizational learning", Journal of Strategy and Management, 12( 1), 103-115.

Lu, L., Lu, A. C. C., Gursoy, D., \& Neale, N. R. (2016). Work engagement, job satisfaction, and turnover intentions: A comparison between supervisors and line-level employees. International Journal of Contemporary Hospitality Management, 28(4), 737-761.

March, J. G., \& Simon, H. A. (1958). Cognitive limits on rationality. Organizations, 1, 136-171.

Memon, M. A., Salleh, R., Harun, H., Rashid, R. A., \& Bakar, Z. A. (2014). Training, engagement, social exchange ideology and employee turnover: A proposed moderated mediation conceptual framework. Australian Journal of Basic \& Applied Sciences, 8(5), 151-156.

Merissa, B. (2018). Pengaruh Work Engagement terhadap Turnover Intention melalui Job Satisfaction sebagai variabel mediasi pada PT. Lotte Shopping Indonesia Sidoarjo. Agora, 6(1). 11-17.

Özçelik, G. (2015). Engagement and retention of the millennial generation in the workplace through internal branding. International Journal of Business and Management, 10(3), 99-111.

Panggabean, S. M. (2004), Manajemen Sumber Daya Manusia. Bogor: Ghalia Indonesia.

Park, J., \& Gursoy, D. (2012). Generation effects on work engagement among US hotel employees. International Journal of Hospitality Management, 31(4), 1195-1202.

Purba, S. D., \& Ananta, A. N. D. (2018). The Effects of Work Passion, Work Engagement and Job Satisfaction on Turn Over Intention of the Millennial Generation. Journal Manajemen dan Pemasaran Jasa, 11(2), 263-274. 
Rachmatan, R., \& Kubatini, S. (2018). The Relationship Between Work Attachment with the Intention to Leave Work at Self-Service Employees in Banda Aceh. Journal Psikogenesis, 6(1), 1-10.

Robyn, A., \& Du Preez, R. (2013). Intention to quit amongst Generation Y academics in higher education. SA Journal of industrial Psychology, 39(1), 1-14.

Samala, N. dan Singh, S. (2018). Millennial's Engagement with Fashion Brands: A Moderatedmediation Model Of Brand Engagement with Self-Concept, Involvement and Knowledge. Journal of Fashion Marketing and Management: An International Journal, 41(8), 705-721.

Schaufeli, W. B., \& Bakker, A. B. (2004). Job demands, job resources, and their relationship with burnout and engagement: A multi-sample study. Journal of Organizational Behaviour: The International Journal of Industrial, Occupational and Organizational Psychology and Behaviour, 25(3), 293-315.

Truxillo, D. M., Bauer, T. N., Erdogan, B. (2016). Psychology and Work: Perspectives on Industrial and Organizational Psychology. Routledge Taylor \& Francis Group. London and New York.

Wheeler, A., \& Harris, P. (2008). Creativity \& Personalization: Freshman Orientation for the Millennial Generation.

Yalabik, Z. Y., Rayton, B. A., \& Rapti, A. (2017, December). Facets of job satisfaction and work engagement. In Evidence-based HRM: a global forum for empirical scholarship, 5(3), 248-265. Emerald Publishing Limited. 